\title{
Analysis of Unfortunate Fate of Pecora in The Bluest Eyes
}

\author{
Zhenzhen Zhang ${ }^{1}$, Hong Yang ${ }^{1}$ \\ ${ }^{1}$ School of Foreign Languages, Hebei University of Technology, Tianjin, 300401, China
}

\author{
Keywords: The bluest Eye. Pecora. Unfortunate Fate
}

\begin{abstract}
The heroine in The bluest Eye was a black girl living in the economic recession time. She was deeply influenced by the culture values admired by mainstream in American society, which is that white represents beautiful. This criterion of beauty has tortured her mental and physical health. Lack of the resistance consciousness, the discrimination between the black people and the discrimination by white grant her to unfortunate life.
\end{abstract}

\section{Introduction}

The Bluest Eye is the masterpiece of famous American writer, Toni Morrison. Pecora despised herself and the figure of self-deprecation. She was born in the black family, with a thought that she was the ugliest girl without white skin and blue eyes. The poverty made her tend to crowd out herself. Considering the life she was living, her mind was so fragile that she wanted to have eyes which were bluer than white children had. She thought that the blue eyes indicating the end of her unfortunate life. However, as if it was doomed, no matter how Pecora thought, no matter how she prayed, it was difficult for her to escape the arrangement of destiny. Her father who did not know how to express his love to his daughter raped Pecora after drunken, which made her pregnant at eleven years old. In addition, that her mother did not trust and beat her and cynicism by around people made her more confused. Only Claudia sister were willing to plant marigold to pray her child safety. However, this last hope was disappeared by the death of her child. As for Pecora, the mental breakdown may be the best ideal end of the novel.

\section{The complete loss of rebellion consciousness}

The family Pecora living was miserable. Her mother, Pauline was lack of confidence by her black skin when she was a child, which made her very cold and lonely, even for her husband and daughter. One of her leg was disabled, married to a very poor man. She was imaging all the day that herself was the victim of the miserable life. She did not think the real meaning of life relied on her practical life, on how to live with husband and daughter, on fulfilling her responsibility, instead of immersing herself into a fantasy and romantic movie plot where she worked in white house and enjoyed great honor from providing service for white people. Pecora's father, Charlie, was the direct reason for her miserable life. Due to that he was humiliated by two white people when he was having sexual relation with others, he vented all of his anger to his girlfriend..

Actually, Pecora was the direct victim of his father's dissatisfaction towards white dominated society. She was always under the shadow of her parents as long as eleven years when she grew up under the inferiority of her parents. The child growing up in this environment was certain to be the one with a strong sense of shame. Thus, it is obvious that Pecora had the incurable trauma. The only thing Pecora learnt from her parents was that they held the pessimistic attitude towards the society with discrimination to them. Her parents never gave consent to her existence, rather than crackdown her confidence. All of these led to her own consciousness becoming more and more weak, which made Pecora pray consistently that herself would disappear as soon as possible.

Due to the lack of rebellion consciousness, Pecora could never resist those adult, like narrator, Claudia, especially those who admitted that their black skin means that they were inferior to the others. In this way, it was impossible for her to have the independent and strong will as Claudia, let alone denial of the aesthetic view of white. However, Pecora folly thought that white skin represents 
beauty, having blue eyes became her dream in her whole life. In her mind, there was no resistance except changing herself. In order to get rid of the humble life, she chose to make friends with Maureen. An ice cream made her feel warm, actually, which gave here the torture when she was compared with a shallow skin girl. A plot in the novel: On the road to home with Claudia sister, a group of boys separate Pecora from Claudia sister, trying to siege her, shouting: "black ghost! Black ghost!" their skin was black as well. They vented their disgusting felling about themselves and hatred abusive way to more marginalized Peora.

What Pecora only could do was to silently bear all of these. Because she thought that she should bear all of these, when she was tricked by Neil who said that she killed the cat, she was called by his mother a dirty little black bitch. When she was chased by her, she did not have any rebellion consciousness at all. Pecora never vented her own dissatisfied emotion and deeply-rooted ignorance and desperation to others, like those who once teased her. What she was lack of was that what Claudia had the resistant courage, a spirit of against power. She accumulated all of despises into her own heart, never trying to find a way to vent. However, people's psychology to bear was very limited. That her father raped her was the turning point of it. Pecora's physical and mental were on the brink of destruction. Meanwhile, it was the blasting fuse of her madness.

\section{Discrimination in black community}

Pecora was unable of getting warm and care from her family, instead of being the main objects her father and mother to vent their emotions. It was imaginable that how others treated her.

When she bought sweet, the owner of grocery saw her in a puzzling way, as if seeing her through. Boys around her always made fun of her. The new friends she made did not comfort her with true heart, instead of trying to satirize her. The black community poured all of the dirty to her, which made her scapegoat among them. That members in this community were scare of black skin and ugly appearance became Pecora's personal highlight deficiencies. Oppression from their black inside community continuously strengthened her desire for blue eyes, making readers see the brutal persecution of black compatriots.

What the irony is that, young figure of Pecora always lingered in people's mind, reminding their own ugliness and un-suppressive intensive hatred. Thus, Pecora's pain symbolized the pain of this community. The author, Morrison proved that they passed pain inside their community was very stupid and cruel. After black people achieved their equal role in law, they were confronted with another new problem. Once racial discrimination and persecution were banned completely, what they suffered were from their inside community. In terms of black themselves, it was impossible for them to get rid of subjective reasons.

\section{White discrimination of white race}

The Bluest Eye seldom mentioned the instance that black was suppressed by white directly, mostly reflecting the white supremacy aesthetic value by contradiction between black, self-denial in their own heart and self-hatred. For a long time, as for the influence of black people, white racism overturned the black soul. Black people regarded the white aesthetic criterion as the standard to measure black beauty and ugliness. Although Pecora was very innocent, promoting the white aesthetic view which was recognized by the whole society, she failed to get blue eyes bringing happiness, instead of losing her rationalism. The irony conclusion leads readers to think about. It is said that this end was caused by racial discrimination leading to an appalling tragedy. Pecora symbolizing self-despise and self-ugliness was the type one in black community. Of course, it is just result of white mainstream culture infiltrating marginal culture. Because of historical reason, the orthodox white culture has been dominant, whose aesthetic view has been accepted by enslaved black people. They even classified themselves into different levels according to their holding of white blood share. In this way, black community completely accepted that black skin was very ugly. Pecora 
agreed with it by nature. This beginning story was the basis of her miserable life, making all of the black community members engross in their own hopeless where they already abandoned themselves.

\section{Blue Eye illusory dream}

All of the pain would make suffering people have fantasy, especially when they were helpless. When Pecora was eleven years old, how could she deal with this fact that she was pregnant her father's child. She had no idea whether to give birth to this child, even the result. Of course, she never thought whether she had the ability to raise this child or to rear him or her. In her mind, what she got was that she was living a miserable life, God and "soap head pastor" were the life-saving straw. As for Pecora, those who were respected, taken care of and given attentions by others and her parents were having blue eyes. She thought innocently that, if her eyes were not black any more and her appearance was the same with those white people, her suffering life would end. Thus, she urged to beauty, fantasizing that her black skin will disappear. She did pray God to make her dreams come true. When she closed her eyes, she fantasized that her body was disappearing. She despised herself so much that she had this illusion, which was the foreshadowing for the end of novel. When people was helpless, they also fantasized they got help from God, such as, God helps them. She thought that God would help her from the suffering life. When she was in deep desperation, she hoped that her body disappeared and owned white skin and blue eyes.

What her fantasy not only reflects, she was keen to attention from the others, but also herself existence meaning and value, revealing that she was deeply influenced by the social environment and fully internalized the white aesthetic view which referred that white skin stands for kind, beautiful and clean, black skin stands for ugliness and dirty. That white skin and blue eyes were beautiful became the criterion respected by others. Pecora always thought that if she had blue eyes, everything would change. Teachers and classmates would like her, her parents will adore her. What she hoped was that her eyes were bluer than others. Bluer eyes would give her more happiness and love and less pain.

In the end, Pecora asked for help from soap head pastor, a shameless lair. He did hurt her deeply again and again. He did have no mercy to her, even taking advantage of her to kill a dog which endangered him. When her child was dead, Pecora was completely destroyed. She tried her best to have blue eyes, which were unable to get attentions and love from others for her, let alone close distance between others. She blinded her own eyes, losing ability to recognize the world where she was the despised one. Once she was more humble and pity, others were happier. She seems to be insignificant in other's eyes. Pecora accepting white aesthetic view and value and trying to have blue eyes, denied herself, burying in her fantasy dream in the end.

\section{References}

[1] Gao Jihai: Pecora Tragedy Retraces-a Review of Toni Morrison The Bluest Eye, Journal of HeNan Normal Univeristy, 2001(3).

[2] QiaoXueying: Analysis of Toni Morrison’s Works from Feminist Perspective, Journal of Sichuan Foreign Language College, 2007(1).

[3] An Lina: Homeless Soul-Inevitability and Implication of Pecora Tragedy in The Bluest Eye, Jouranl of Qiqihaer Unveristy(Philosophy and Social Science edition), 2009(4).

[4]Xiao Hongzhi: Destruction and Survival-Comparison Claudia Fate and Pecora Fate in The Bluest Eye, Journal of Border Economy and Culture, 2009(9).

[5] Yin Yanfang: Alienation of the Subject-Analysis of Madness of Pecora in The Bluest Eye, Journal of Zhengzhou Aviation Industry Management College(social science edition), 2010(6). 